\title{
Determinants of Africa - BRIC Countries Bilateral Trade Flows
}

\author{
Cosmas S. Mbogela ${ }^{1}$ \\ 'Mzumbe University Business School, Box 6 Mzumbe, Tanzania \\ Email:cmbogela@gmail.comTel:+255766599295
}

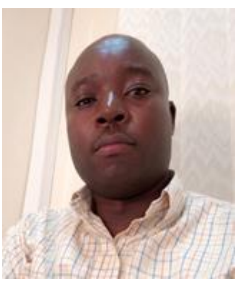

\begin{abstract}
This paper uses gravity models to take advantage of the possibility to explicitly test the changes in trade patterns over time and examine how these changes differ across different regions in question. Using gravity models, the paper examines the determinants of trade flows of African countries with the emerging trading partners to Africa, namely Brazil, Russia, India and China (the BRIC). These countries are part of the five largest emerging economies that accounts for about 20 per cent of the world output and 27 per cent of the global trade flows. The study models some new variables in gravity models such as credit to private sectors, arable land as well as mobile cellular subscriptions. The paper highlights some important truths, African countries where most of this bilateral trade with BRIC is concentrated includes those countries which are rich in natural resources, and in most cases they are the same with higher GDP per capita among the African countries. The coefficients variable arable land takes a positive sign with high statistical significance for the BRIC - Africa trade flow; and it indicate that the size arable land tend to statistically explain 65 per cent of the variations on exports for the bilateral trade flows. The coefficients for the mobile cellular variable indicate a positive effect on the trade from BRIC to Africa. Mobile phones usage has a great potential to enhance the bilateral trade volumes of the African countries as well considering the limited infrastructural setup in the continent.
\end{abstract}

Keywords: Gravity model, Bilateral trade, Trade flows, Panel data, Fixed effects model, Random effect model, BRIC countries JEL Classification: F1, F3, F4, F6.

Citation | Cosmas S. Mbogela (2018). Determinants of Africa BRIC Countries Bilateral Trade Flows. Economy, 5(1): 40-53.

History:

Received: 18 September 2018

Revised: 22 October 2018

Accepted: 28 November 2018

Published: 24 December 2018

Licensed: This work is licensed under a Creative Commons

Attribution 3.0 License $(\mathrm{cc})$ E

Publisher: Asian Online Journal Publishing Group
Funding: This study received no specific financial support.

Competing Interests: The author declares that there are no conflicts of interests regarding the publication of this paper.

Transparency: The author confirms that the manuscript is an honest, accurate, and transparent account of the study was reported; that no vital features of the study have been omitted; and that any discrepancies from the study as planned have been explained.

Ethical: This study follows all ethical practices during writing.

\section{Contents}

1. Introduction. 41

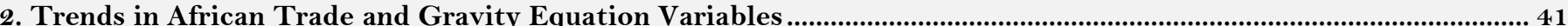

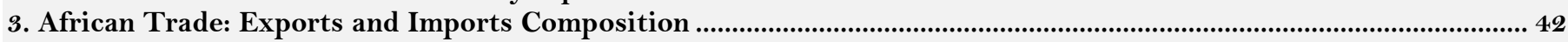

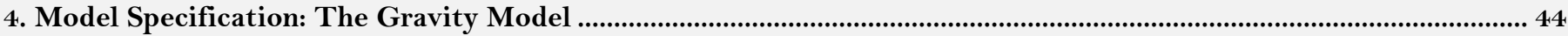

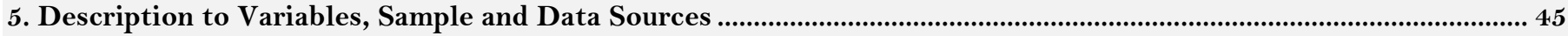

6. Dealing with Zero-Valued and Missing Trade Flows …......................................................................................................... 45

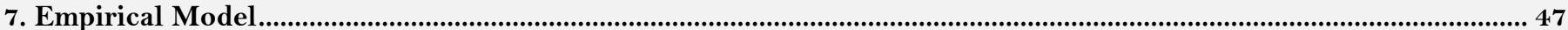

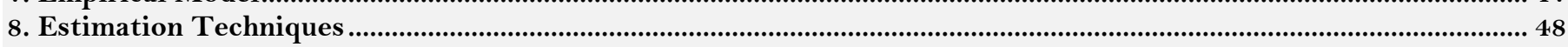

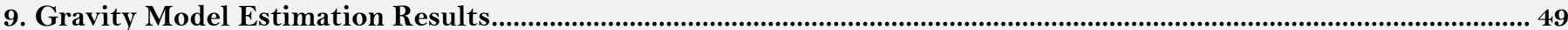

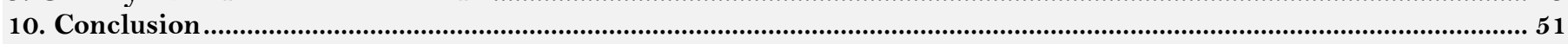

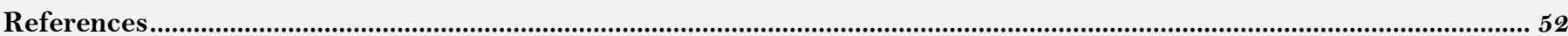




\section{Introduction}

Studies on the analysis of bilateral trade flows between a pair of countries have considered either developing countries alone or a pair of developing and developed country (Zannou, 2010; Baldwin and Taglioni, 2011; De Castro, 2012). For most of the studies developing countries have been considered as a dummy variable with an argument that, including developing and developed countries in the same sample for regression analysis results into biased results hence a heterogeneity problem (Fontagné and Freudenberg, 2002). It is also argued that the economic difference between these economies being so huge make income likely to be a substitute for differences in degree of development instead of the ability of income growth to stimulate trade (Tansey and Touray, 2010 ). Nevertheless, the literature also asserts that differences in economic size among countries will encourage more trade (Islam et al., 2014) this contention is worthy examining by having a sample that contain economies that differs in size.

This paper examines the determinants of trade flows of African countries with the emerging trading partners to Africa, namely Brazil, Russia, India and China (the BRIC ). These countries are part of the five largest emerging economies (the other being South Africa) that accounts for about 20 per cent of the world output and 27 per cent of the global trade flows (De Grauwe et al., 2012). Their shares in the world merchandise exports in 2011 were 11 percent (China), 3 per cent (Russia), 2 per cent (India) and 1 per cent (Brazil).

While for some decades now the OECD accounted for the largest share of African trade, as it can be seen from the table above the trend is now changing, the share of non-OECD countries in Africa's trade has increased from 26.4 per cent in 2000 to 39.4 per cent in 2009. China (taken as a single country) may soon take a lead considering the rate of growth with which it trades with African countries. For instance, China's share in the Africa's trade has risen from less than 1 per cent (1980's) to 13.5 per cent (Africa's imports) and 11 per cent (Africa's exports) in 2009; besides China accounts for more than any individual European country in Africa's trade (De Grauwe et al., 2012). In 2011, as Africa's largest trading partner, China's trade deals totalled \$160 billion.

Table-1. African trade by trading partner

(Figures as a percentage of total African merchandise trade)

\begin{tabular}{l|l|l|l|l}
\hline & $\mathbf{1 9 9 2}$ & $\mathbf{2 0 0 0}$ & $\mathbf{2 0 0 5}$ & $\mathbf{2 0 0 9}$ \\
\hline OECD & 81.8 & 73.6 & 68.5 & 60.6 \\
\hline Intra Africa & 3.4 & 9.8 & 9.5 & 9.2 \\
\hline Brazil & 1.0 & 1.6 & 2.3 & 2.5 \\
\hline China and Hong Kong & 1.7 & 4.2 & 7.6 & 13.5 \\
\hline India & 1.3 & 2.1 & 2.1 & 4.9 \\
\hline Russia & $\ldots$ & 0.5 & 0.7 & 1.0 \\
\hline Total & $\mathbf{8 9 . 2}$ & $\mathbf{9 1 . 8}$ & $\mathbf{9 0 . 7}$ & $\mathbf{9 1 . 7}$ \\
\hline Non OECD Total & 18.2 & 26.4 & 31.5 & 39.4 \\
\hline
\end{tabular}

Source: OECD Report, 2011

Though bilateral trade has been widely examined, no study has done a research concerning African countries trade flows with the largest emerging economies where this study takes on and considers four of the BRICS economies (see Table 1). Some new variables are also included such as credit to private sectors operation in the economy, arable land as a percentage of total land mass as well as mobile cellular subscriptions. Furthermore, the study is different from many other gravity model studies in terms of the empirical analysis that is applied. An advantage of using gravity model in a panel dataset is that it is possible to explicitly test the changes in trade patterns over time and examine how these changes differ across different regions in question. This is more thoroughly done than just clumsily examining trade patterns changes in a particular one year as can be expected in cross section studies.

The examination is conducted by use of the renowned gravity model technique, which has proved to be powerful in explaining different scenarios in international trade issues, particularly bilateral trade. It employs an instrumental Variable (IV) estimation technique developed by Hausman and Taylor (1981) in order to take care of the endogeneity and biasness resulting from omission of variables.

The rest of the paper will proceed as follows; following will be the review of salient literature on the dynamics of bilateral trade in the African countries, thereafter the general model is specified together with a description of data for the study. Section three provides the estimation technique, followed by empirical results and discussion. Finally, a conclusion and policy implications is presented.

\section{Trends in African Trade and Gravity Equation Variables}

According to World Bank (2013) from 1960-2011 Africa's exports grew at a mean rate of 2.6 percent per annum. The mean annual growth rate of imports was faster than that of the exports, at 4.1 percent. While for SubSaharan Africa alone the export mean growth rate was almost similar to imports rate that is, 1.8 for exports and 2.1 for imports. Likewise, the total trade as a percentage of GDP for Africa as a whole had a mean value of 55.7 percent with a mean growth rate of 0.24 per cent per annum. It is therefore obvious that for over the past five decades exports grew at a lower rate than the imports did. Besides, the growth of total trade as a percentage of GDP has been very small (less than 0.5 p.a) over the past 52 years. Contrary to the BRIC countries which for the same period experienced the growth of their exports at a mean rate of 9.05 per cent while imports grew at a rate of 5.7 per cent. As for the OECD countries, exports grew at a mean rate of 7.4 per cent, while imports at a mean rate of 5.6 per cent.

Taking Sub Sahara African alone (excluding South Africa and Nigeria), the data shows an even a worse picture. For the same period (from 1960 to 2011), the exports grew at a mean annual rate of 0.1 percent, while imports at 2.2 per cent. The mean value for the total trade as a ratio of GDP for the whole period was 55.9 per cent and had been declining at a mean rate of 0.01 annually. The volume of trade as a ratio of GDP has been declining despite the fact that Africa's GDP rate of annual growth has been 3.8 per cent on average for the whole period from 1960 to 2011 (WB, 2013). This confirms the claim by Coe and Hoffmaister (1999) that despite the fact that Africa's GDP 
has been growing more slowly than other regions since 1970's, it has risen more rapidly than trade. Compared to Asia and Latin America countries during the same period; to these regions trade has increased more rapidly than their respective GDP. Thus what is observed in Africa is contrary to the predictions of the gravity model, which predicts that the trade volumes between countries increase as their respective GDP increases.

Specifically, the standard gravity model predicts the trade intensity between countries by using their respective economic size and the distance between them. However, Coulibaly and Fontagné (2006) argue that the existence of untapped trade potentials in the Sub Sahara African countries trade proves that the limited intra-sub Saharan African trade is not justified by the economic size of the exporting and the importing economies. On the contrary, they argue that geography, the fact that Africa has a large percentage of landlocked countries coupled with poverty which creates trading costs. Generally landlocked countries are disadvantaged in terms of trade, however comparatively African countries that are landlocked are more disadvantaged than the developed landlocked countries. This is because they trade less than their counterparts. On average, the export ratio for SSA land locked countries is less than 30 percent while the developed countries' landlocked country is 50 percent. However, the total trade as a ratio of GDP data reveals that for the period from 1990 to 2012 average trade ratio mean value for the non-landlocked African countries is 71.68 per cent while for landlocked African countries was 65.81 per cent while that of developed countries was 139. 91 percent (WB, 2013).

Table-2. Mean values of trade volume as a ratio of GDP for the period from 1990 to 2012

\begin{tabular}{|c|c|c|c|c|c|}
\hline \multicolumn{4}{|c|}{ Developing landlocked countries - African Countries } & \multicolumn{2}{|c|}{ Developed landlocked Countries - OECD } \\
\hline & $\%$ & & $\%$ & & $\%$ \\
\hline Botswana & 89.9 & Mali & 59.2 & Czech Republic & 113.8 \\
\hline Burkina Faso & 34.7 & Niger & 44.3 & Hungary & 115.9 \\
\hline Burundi & 33.8 & Rwanda & 35.2 & Luxemburg & 256.2 \\
\hline $\begin{array}{l}\text { Central } \\
\text { Republic }\end{array}$ & 36.2 & Swaziland & 143.8 & Slovak Republic & 132.6 \\
\hline Chad & 65.5 & Uganda & 36.9 & Switzerland & 80.88 \\
\hline Ethiopia & 32.6 & Zambia & 69.3 & & \\
\hline Lesotho & 166.3 & Zimbabwe & 75.9 & & \\
\hline Malawi & 63.6 & & & & \\
\hline \multicolumn{3}{|c|}{ Average mean for all landlocked countries } & 65.81 & \multicolumn{2}{|l|}{139.91} \\
\hline \multicolumn{3}{|c|}{ Average mean for non-landlocked countries } & 71.68 & \multicolumn{2}{|l|}{73.27} \\
\hline
\end{tabular}

Source: Author's calculations on the WB (2013) data.

The table above provides a more detailed mean values; Swaziland and Lesotho are outliers probably because they are countries surrounded by South Africa which has been the strongest economy in Africa for so long. before Nigeria took the top position (BBC News Business, 2014). It can therefore be argued that the geographical and infrastructural characteristics poses a sizable obstructions on bilateral trade in the SSA countries (Coulibaly and Fontagné, 2006) a 10 percent increase in the paved roads that joins a pair of two trading countries is believed to induce a 17 to 30 per cent in trade between the two countries. This only means that transport costs are higher for African land locked countries than it is with the developed land locked countries.

A more related to geography is the distance variable; the distance variable is one of the trade impeding features in the gravity model studies. The standard gravity model predicts that bilateral trade between any two countries is negatively related to the distance between the two trading countries. While it has been argued that the distance variable works in favour of economies that are in the same continent or region (Tansey and Touray, 2010) there has also been a considerable discussions about the death of distance due to technological advancement (Kolko, 2000; Cairncross, 2001; Capling and Nossal, 2001).

There are arguments that the global increase in trade can be attributable to a decrease in the distance between countries which is reflected by a fall in transportation costs in terms of ocean freight rates, air freight rates and overland transport costs. There are studies that have made an attempt to link trade growths to changes in transport costs (as measured by IMF c.i.f. /f.o.b. ratios) among other factors (Rose, 1991; Krugman, 1995; Baier and Bergstrand, 1997). The technological advancement in communications, the post second world war (WW II) development of jet aircraft engines and the use of containerisation in the ocean shipping has led to lower shipping costs, as well as other transportation costs that has been linked to an increase in international trade (Hummels, 2007).

\section{African Trade: Exports and Imports Composition}

Merchandise exports in Africa are dominated by primary commodities (mainly minerals and fuels products) and these are mainly exported outside the continent. Nevertheless, there are good stories in the intra-African trade, the fact that the goods that dominate the intra African trade are manufacturing goods. Data reveals that the share of manufactured goods in intra-African trade is higher than its share of manufacturing goods in the African trade with countries outside the continent. This is true for the past two decades irrespective of the fact that this sector is not yet fully exploited relative to other sectors in the continent (UNCTAD, 2013). The main manufactured goods being traded between partner countries includes cotton fabrics, machinery parts, gold in semi manufactured forms, plywood, aluminium alloy plate, tea in packages, portland cements, cigarettes containing tobacco, medicaments, vegetables fresh and chilled, cashew nuts fresh and dried etc.

The Figure 1, below compares the volume of trade by sectors and it reveals that the intra African trade is mainly dominated by manufacturing sector for the whole of the two decades. Trade in minerals fuels, lubricants and related materials is second to manufacturing sector, leaving behind the agricultural sector (i.e. food and live animals, animal and vegetable oils, fats and waxes), which is the backbone for many of the African countries' population income wise as well as for provision of employment. 


\section{Africa - Intragroup trade 1995 to 2012}

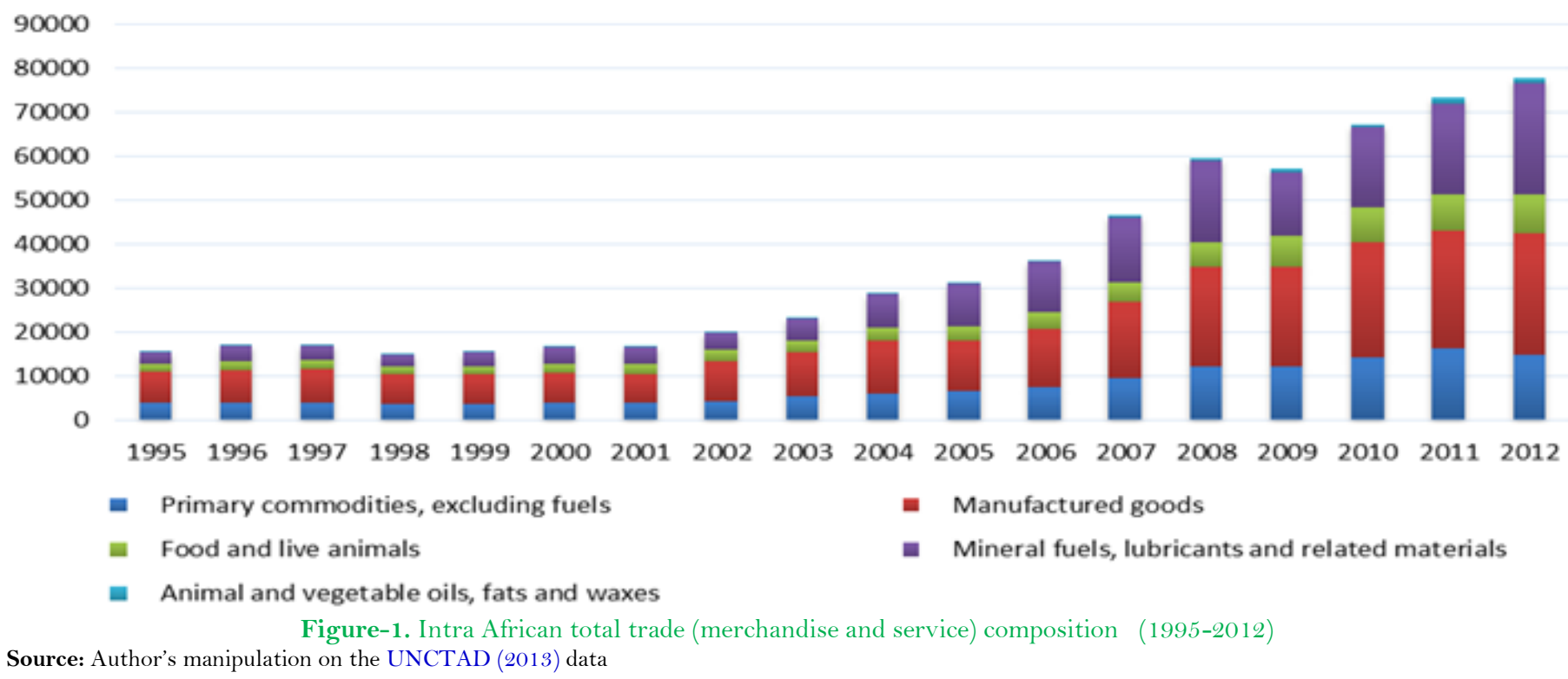

A different picture is seen on the part of African trade with the rest of the world (Figure 2). A large percentage of external exports and especially from year 2000 has been mainly in mineral fuels, lubricants and related materials. A large part of Africa's natural resources feeds Asian and European countries' industries. Primary commodities (excluding fuels) are second to minerals and fuel sector, and provides a hint on the same idea of African external trade being dominated by primary commodities.

However, the intra-regional trade ratio in Africa is remarkably low compared to industrialised countries although it doubled from 6 per cent (in 1990) to 12 per cent (in 2011). Reasons could be because most countries in the African continent have their production and export structures such that the focus is on primary commodities like fuel, minerals and agricultural products. And since most countries have similar structures (Shinyekwa and Lawrence, 2013) they cannot satisfy their mutual import needs therefore leaving them with an option of satisfying the external market.

Africa trade to the rest of the World 1995 to 2012

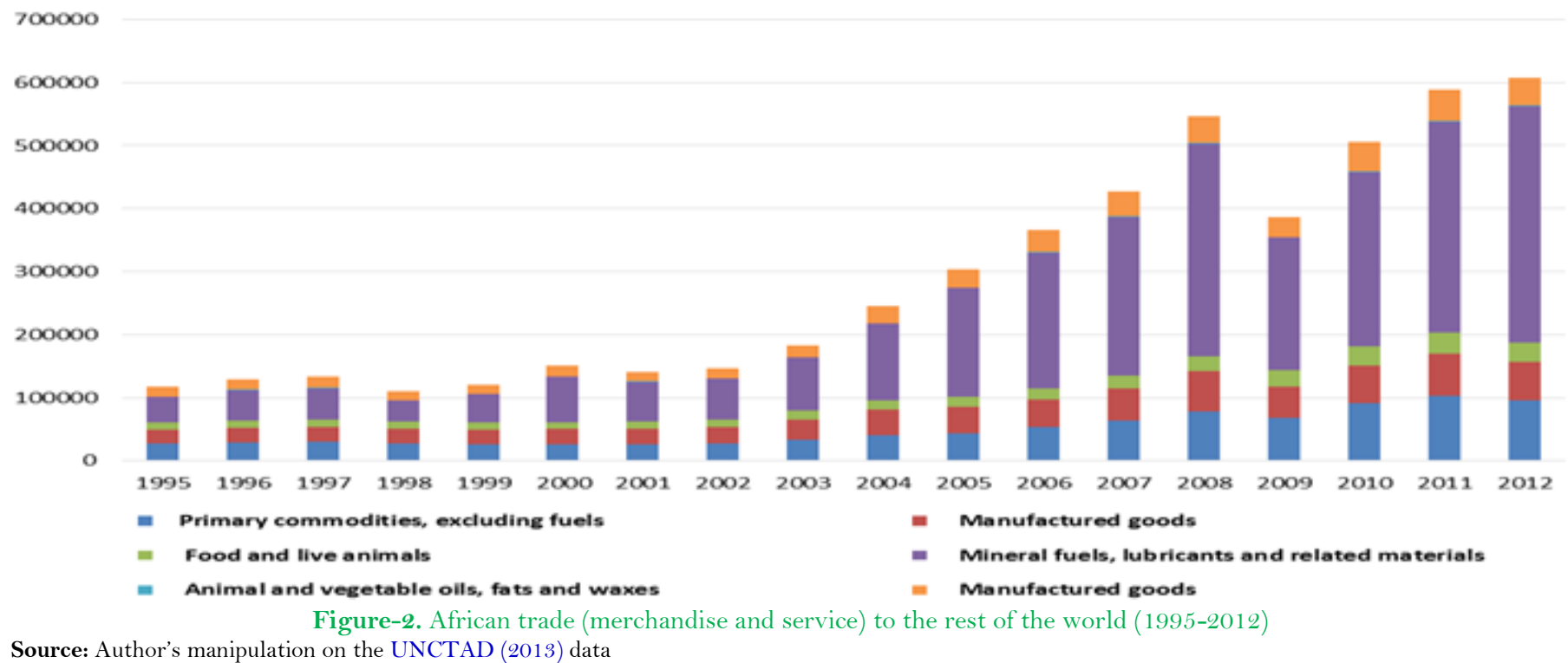

Consequently, the direction of the African's trade with the rest of the world follows the same traditional links (chiefly to Europe). Therefore, the reason why the intra-regional trade ratios remain persistently low is that more than 80 per cent of the continents exports are destined for external markets. Likewise for imports; large part of imports comes from markets outside the continent (UNCTAD, 2013). Besides, as pointed out earlier, inadequate and unreliable infrastructure cannot be neglected as another major reason for lower intra-regional trade.

Over the past decade, the share of Africa's traditional export markets has been maintained whereas the continent's share of exports of emerging economies (BRICS) import markets has increased significantly. After the recent financial crisis, the growth in exports to the BRICS is to a large extent explained by the rising in commodity prices. In 2009, the value of African exports fell by 31 per cent and grew by 25 per cent in 2010, and the volume of imports fell by 11 per cent and consequently mended by 9 per cent in the respective years. Which means price effects described virtually two thirds of the growth in trade values (UNCTAD, 2013). 
Manufactured goods

Mineral fuels, lubricants and related materials

Primary commodities, excluding fuels

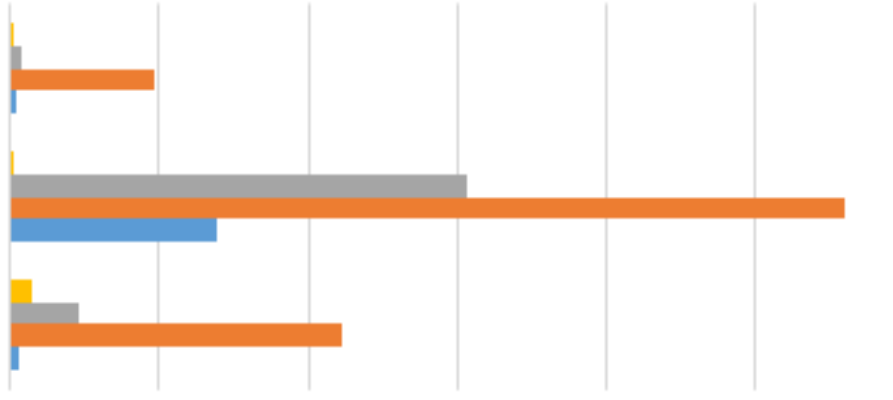

$10,000 \quad 20,000 \quad 30,000 \quad 40,000 \quad 50,000 \quad 60,000$

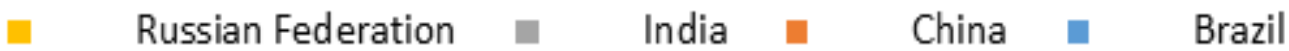

Figure-3. Africa Merchandise trade with the BRIC countries (product groups, exports in millions of dollars, annual, for 2012) Source: Author's manipulation on the UNCTAD (2013) data

This trend of Africa diversifying its exports market towards emerging partners has seen China's export and import figures gradually progressing from one of the least among the top ten trading partners to Africa to the largest ones over the last decade, becoming the second after USA in 2010. In 2010 alone, 12.5 per cent and 4 percent of Africa exports went to China and India respectively, which represented 5 per cent and 8 per cent of these countries' imports respectively. As depicted in figure 15 and 16 above, African exports to these emerging countries is characterised by concentration of minerals and fuels.

There is much concentration trend of the products dominating the exports from Africa to each of the BRIC countries (UNCTAD, 2013). It can be argued that the driving force behind BRIC -African trade boom is natural resources available in the African countries. This is because exports to Brazil, China and India represent a significant part of mineral oils being exported from African countries to the BRIC. For this matter therefore there is a concentration of this booming trade to certain African countries with major sources of natural resources. According to World Bank data, the top in the list of trading partners includes Angola, Sudan, Nigeria, Republic of Congo, Libya and Algeria. All these countries have mineral fuels as the main product for their exports (Drummond and Liu, 2013). For instance, considering China alone, its engagement with Africa portrays an increasing trend with African share in the Chinese mineral fuels import market increasing from less than 5 per cent in 1995 to 25 per cent in 2011 (UNCTAD, 2013). The other countries in the list include South Africa, Benin, Morocco and Egypt. The latter have a diversified economy so they export agricultural products and manufactured products. Russia is a leading importer of these products among the BRIC, followed by China and India.

\section{Model Specification: The Gravity Model}

This paper uses gravity model to estimate the determinants of bilateral trade flows of Africa. The application of the model to analyse international trade flows traces back to Tinbergen (1962). Since then the gravity model has gained great interest of the researchers due to its powerfulness in explaining different scenarios in international trade issues; such as testing the effect of a common currency, or membership in regional integrations agreements on bilateral trade (Guttmann and Richards, 2006). It is a model that gives clear and robust economic empirical findings on international trade issues (Haveman and Hummels, 2004). In the context of international trade flows, the theory asserts that the volume of trade flows between two trading partners is defined by the supply conditions at the country of origin, demand conditions at the country of destination and stimulating or restraining factors that are related to the trade flows between the two trading partners (Serlenga and Shin, 2004).

According to Baier and Bergstrand (1997) and Zannou (2010) in the earlier days of its usage, the gravity model was lacking a formal theoretical foundation, only to be provided by the empirical investigations by Anderson (1979); Krugman (1979); Krugman and Elhanan (1985); Deardorff (2011); Evenett and Keller (2002); Feenstra et al. (2001). They represent the gravity model to be a reduced form that is derived theoretically from a general equilibrium model of international trade in final goods. Two countries GDPs are taken to be the production and absorption capacities of the two exporting and importing countries respectively; whereas the geographical distance represents the transportation costs, more distance meaning greater costs (Baier and Bergstrand, 2001).

The starting point for any specification of the gravity model must be a consideration of the flow of goods $\left(X_{i j}\right)$ between two countries $i$ and $j$; whereas, the flow of goods between the two, would depend on the characteristics of the country of origin $\left(A_{i}\right)$ and those of the destination country $\left(B_{j}\right)$ as well as the measure of resistances and motivational factors to bilateral trade that exists between the two countries $\left(\boldsymbol{R}_{i j}\right)$. Hence, the multiplicative form of the gravity equation;

$$
X_{i j}=G^{*} A_{i} * B_{j} * R_{i j}
$$

To put it in the typical terms of the gravity model tradition, Xij represent the monetary value of exports from country i to j; the $G$ denotes some variables that do not depend on either of the two countries, also known as gravitational constant (e.g. globalisation level). Ai stands for factors that are specific to an exporting country (e.g. exporter's GDP); Bj comprises of all the importer specific factors that make up the total importer's demand (e.g. importer's GDP).Rij signifies the ease with which the exporter country can access the importer's market $\mathrm{j}$, in some other studies (Drysdale and Garnaut, 1982) $R_{i j}$ stands for resistances to trade between $i$ and $j$. The $R_{i j}$ is more defined in Deardorff (2011) who presents it as a measure of distance between the two countries, the combined effect of the two factors (size and distance) is known as the gravity term and it is normally expressed as the product of the output of the two trading partners divided by the distance between them (Musila and Sigué, 2010) the result of which is the model below:

$$
T_{i j}=G^{*}\left[\left(\Upsilon_{i t} * Y_{j i}\right) / D_{i j}\right]
$$


Where; $\mathrm{T}_{i j}$ represents the value of exports from country $i$ to country $j ; \Upsilon_{i}$ and $\Upsilon_{j}$ are their respective national incomes; and $D_{i j}$ represents a measure of distance between them; and $G$ is a gravitational constant. The national incomes shows the economic size of the exporting country and hence determines the quantity of goods that it can produce and export, while the economic size of the importing country determines the capacity of its market to purchase the imported goods. On the other hand, the distance variable represents the transportation costs that will determine the volume of goods that will be traded. The distance variable is considered as a resistance/motivating factor as it can either promote or hinder trade flows between countries (Sichei et al., 2011). This reflects that transport costs in international trade flows increases with distance.

Gradually, new explanatory variables were added to the model in order to capture more country specific characteristics. The literature reckons the augmentation of such variables as population (Linnemann, 1966a) income per capita and contiguity (Sanso et al., 1993; Frankel et al., 1995; Eichengreen and Irwin, 1998; Frankel and Wei, 1998). Moreover, variables that captures geographic features, economic development and policy institutions, were included in the model as explanatory variables resulting in an augmented gravity model which is in use in most of the most current literature like that of Guttmann and Richards (2006); Zannou (2010) and Vicard (2011). The augmented gravity model came to be presented as;

$$
T_{i j t}=\beta_{o} Y_{i t}^{\beta_{1}} Y_{j t}^{\beta_{2}} P_{i t}^{\beta_{3}} P_{j t}^{\beta^{\beta_{t}}}{D_{i j} \beta_{5}}_{\beta_{i j}}^{\beta_{6}} \eta_{i j t}
$$

Where; $\beta_{o}$ is the constant of proportionality; $Y_{\text {it }}\left(Y_{j t}\right)$ is the GDP of the country $i$ and $(j) ; \boldsymbol{P}_{i t}\left(\boldsymbol{P}_{j t}\right)$ are populations of country $i$ and $(j) ; D_{i j}$ represents a measure of distance between the two countries; $M_{i j}$ represents any dummy variables that can be included in the model; $\eta_{i j t}$ is the error term and $\beta$ s are the parameters of the model.

From the original standard gravity model in a multiplicative form, the standard procedure for estimating the model is by making the application of natural logarithms of all variables so as to obtain a log linear equation that can easily be estimated by the Ordinary Least Squares (OLS) regressions as well as other estimation methods (Tripathi and Leitão, 2013). In estimating a gravity model, the inclusion of all the surveyed variables can be done; but the issue is whether all countries and most especially the less developed countries have their data included in the dataset of the samples previously used (Baltagi et al., 2003). Hence, though the number of variables may vary depending on the nature of estimations required, the log linear form of the model can be presented follows;

$$
\log T_{i j t}=\beta_{o}+\beta_{i} \log Y_{i t}+\beta_{2} \log Y_{j t}+\beta_{s} \log P_{i t}+\beta_{t} \log P_{j t}+\beta_{s} \log D_{i j}+\beta_{6} M_{i j}+\eta_{i j t}(i v)
$$

The classical gravity models were basically used in a cross section studies so as to estimate trade effects or trade relationships for a particular time period (Baltagi et al., 2003). One of the first studies that applied gravity model in the panel data studies to account for country pair effects instead of exporter and importer effects was the study by Hummels and Levinsohn (1995). And it is now the most adopted approach by majority of the current studies on the determinants of trade volumes. The advantage for this is that the fixed country-pair effects controls for the impact of any time-invariant factors such as bilateral distance, common language, historical relations, membership to regional trading groups and contiguity.

Besides, the use of country-pair effects removes any possibility for biasness resulting from error of omission due to the omission of any such variable (Baltagi et al., 2003). The Panel data approach allows for more variation in the data and hence assuring more efficiency in data handling, and reduction in the degree of multicollinearity in the variables (Baltagi and Kao, 2000). This paper use panel data for the sample of countries that are examined.

\section{Description to Variables, Sample and Data Sources}

The data for this paper were obtained from different databases and compiled to fit the analysis as indicated in the table below. The main databases included the World Bank development indicators, Centre d'Etudes Prospectivesetd'Informations Internationales (CEPII) gravity dataset, WTO database and the IMF direction of trade statistics database. The sample period is 32 years (from 1980 to 2012 all inclusive). The reason for this sample period is because most of African countries have at least complete dataset from 1980's, so to avoid a large number of gaps in the dataset 1980 to 2012 was appropriate. The paper considers a bilateral trade flows between African countries and the BRICs countries (41 African countries and 4 BRIC countries).

\section{Dealing with Zero-Valued and Missing Trade Flows}

The study uses logarithmic transformation in most of the variables so as to enable for the estimation of the log linear equation (Coe and Hoffmaister, 1999). However the data that is used is a bilateral trade flow data in most cases has either missing values or many zero trade flow observations. And for the case of African trade flows some observations are even missing. The zero data values normally would imply absence of any trade at all (Bikker, 1987) however this would be the case for a carefully prepared datasets. Otherwise, they could be caused by nonreporting of the trade flows between pair of countries. It could also reflect errors or omission during the preparation of the datasets (Martin and Pham, 2015).

Even if there are zero values still the study would want to examine the trade flows because if two countries have zero flows it imply that they are small or they are distant countries or both, thus the gravity model predictions would be either very low bilateral flows or non-existent (Frankel et al., 1997; Coe and Hoffmaister, 1999). The logarithmic transformation cannot be possible with zero observations because the log of zero is undefined (or minus infinity). Thus doing such transformation prior to dealing with the available zero observations would result into biased and inconsistent estimation results. Likewise if the zero flows are disregarded by omitting them in the dataset, the information to explain why there is very low trade cannot be obtained. Same kind of problems occurs in case there are missing values in the dataset, hence these calls for a solution. 
Table-3. Description of variables, data sources and expected relationship

\begin{tabular}{|c|c|c|c|}
\hline Variable & Description & Source & Expected sign \\
\hline Exports & $\begin{array}{l}\text { Measures the total exports from one } \\
\text { trading partner to another in the } \\
\text { country pair. The exports variable } \\
\text { accounts for both flows from country A } \\
\text { to B as well as country B to A. }\end{array}$ & $\begin{array}{l}\text { IMF Direction } \\
\text { of } \quad \text { Trade } \\
\text { Statistics }\end{array}$ & This is the dependent variable. \\
\hline $\begin{array}{l}\text { GDP } \quad \text { per } \\
\text { capita }\end{array}$ & $\begin{array}{l}\text { Measures of the level of economic } \\
\text { development of an economy. The GDP } \\
\text { per capita data are in constant } 2005 \text { US } \\
\text { dollars. }\end{array}$ & WB (2013) & $\begin{array}{l}\text { The sign for coefficients is expected to } \\
\text { be positive as in Zannou (2010) }\end{array}$ \\
\hline $\begin{array}{l}\text { Geographical } \\
\text { Distance }\end{array}$ & $\begin{array}{l}\text { Measure of the geographical distance } \\
\text { between the capital cities of pair of } \\
\text { countries. }\end{array}$ & $\begin{array}{l}\text { CEPII } \\
\text { gravitydataset }\end{array}$ & $\begin{array}{l}\text { The level of trade between a pair of } \\
\text { countries is a negative function of the } \\
\text { distance between trading pair } \\
\text { countries (Rose and Van Wincoop, } \\
\text { 2001) }\end{array}$ \\
\hline $\begin{array}{l}\text { Population } \\
\text { size }\end{array}$ & $\begin{array}{l}\text { Measure of the total population of a } \\
\text { country }\end{array}$ & WB (2013) & $\begin{array}{l}\text { Studies finds a different relationship } \\
\text { depending on if a country is an } \\
\text { importing and exporting country } \\
\text { (Kimino et al., 2007; Zannou, 2010). } \\
\text { The expected sign is positive. }\end{array}$ \\
\hline Landlocked & $\begin{array}{l}\text { Measures the number of countries } \\
\text { without access to the sea/ocean in each } \\
\text { country pair (i.e. } O \text { if not one country in a } \\
\text { pair is landlocked, } 1 \text { if one country in a } \\
\text { pair is landlocked or } 2 \text { if both are) }\end{array}$ & $\begin{array}{l}\text { CEPII gravity } \\
\text { dataset }\end{array}$ & The expected sign is negative. \\
\hline $\begin{array}{l}\text { Common } \\
\text { language } \\
\text { official }\end{array}$ & $\begin{array}{l}\text { Measure of whether countries in a pair } \\
\text { share official common language. The } \\
\text { variable takes the value of } 1 \text { for countries } \\
\text { using common language and } O \text { for } \\
\text { countries that do not. }\end{array}$ & $\begin{array}{l}\text { CEPII gravity } \\
\text { dataset }\end{array}$ & $\begin{array}{l}\text { Similarity in countries encourages } \\
\text { bilateral trade and therefore similarity } \\
\text { in language has a positive effect on } \\
\text { trade (Balassa, 1966; Frankel and } \\
\text { Rose, 2002) }\end{array}$ \\
\hline $\begin{array}{l}\text { Membership to } \\
\text { WTO }\end{array}$ & $\begin{array}{l}\text { A measure of whether countries in a pair } \\
\text { are member to WTO (i.e. } O \text { if not one } \\
\text { country in a pair is a member, } 1 \text { if one } \\
\text { country in a pair is a member or } 2 \text { if both } \\
\text { are). }\end{array}$ & $\begin{array}{l}\text { WTO database, } \\
2013\end{array}$ & $\begin{array}{l}\text { It is expected that the coefficients will } \\
\text { be positive. }\end{array}$ \\
\hline $\begin{array}{l}\text { Mobile } \\
\text { cellular } \\
\text { subscription: }\end{array}$ & $\begin{array}{l}\text { Measures the subscriptions to public } \\
\text { mobile telephone services using cellular } \\
\text { technology that provides access to the } \\
\text { public switched telephone network. It } \\
\text { represents a percentage of the total } \\
\text { subscriptions to public telephone } \\
\text { network. }\end{array}$ & WB (2013) & $\begin{array}{l}\text { Mobile cellular subscription is } \\
\text { considered as a factor that positively } \\
\text { influences the trade flows between } \\
\text { African countries and outside the } \\
\text { continent, hence positive coefficients. } \\
\text { This is based on the fact that not only } \\
\text { it simplifies communication, but also } \\
\text { enables the users to use mobile } \\
\text { banking facility (for settling } \\
\text { transaction bills).thus reducing } \\
\text { transaction costs in bilateral trade. }\end{array}$ \\
\hline $\begin{array}{l}\text { Arable land as } \\
\text { a percentage of } \\
\text { total land }\end{array}$ & $\begin{array}{l}\text { A measure of the total size of arable land } \\
\text { as a proportion of the total land in each } \\
\text { country in a pair. }\end{array}$ & WB (2013) & $\begin{array}{l}\text { Arable land is more closely related to } \\
\text { a country's productive capacity than } \\
\text { the total land (Baxter and Kouparitsas, } \\
\text { 2006). The expected sign is positive } \\
\text { coefficients reflecting a positive impact } \\
\text { to the bilateral trade flows. }\end{array}$ \\
\hline $\begin{array}{l}\text { Domestic } \\
\text { credit to } \\
\text { private sector }\end{array}$ & $\begin{array}{l}\text { Measures all the financial resources } \\
\text { provided to the private sector, such as } \\
\text { through loans, purchases of non-equity } \\
\text { securities, and trade credits and other } \\
\text { accounts receivable, that establish a } \\
\text { claim for repayment (WB, 2013). }\end{array}$ & WB (2013) & $\begin{array}{l}\text { The role played by private sector is } \\
\text { paramount in the trade flows between } \\
\text { economies. The expected sign for the } \\
\text { coefficients of this variable is positive. }\end{array}$ \\
\hline $\begin{array}{l}\text { Bilateral } \\
\text { exchange rate }\end{array}$ & $\begin{array}{l}\text { Refers to the exchange rate determined } \\
\text { by national authorities from which a } \\
\text { bilateral exchange rate (cross rate) is } \\
\text { computed by the researcher. }\end{array}$ & WB (2013) & $\begin{array}{l}\text { Generally changes in exchange rate } \\
\text { index has a significant negative impact } \\
\text { on the volume of exports because for } \\
\text { risk averse market participants, } \\
\text { exchange rate uncertainty causes them } \\
\text { to reduce their activities, change } \\
\text { prices, or shift sources of demand and } \\
\text { supply in order to minimize their } \\
\text { exposure to the effects of exchange } \\
\text { rate volatility (Chowdhury, 1993; De } \\
\text { Vita and Abbott, 2004). }\end{array}$ \\
\hline
\end{tabular}


There are many solutions to this problem as suggested by the literature (confer, e.g. Linders and De Groot (2006); Foroutan and Pritchett (1993)). The most resorted solution is to ensure that the sample is selected such that is does not contain observations with zero or missing values. However sometimes this is difficult especially when the aspiration is to have as broader sample size as possible. This approach has been adopted by such authors as Frankel et al. (1997) and Bikker (1987). Another solution/approach would be to arbitrarily substitute small number values for all observations with zero and missing values. This would enable the logarithmic transformation process be correctly done. Example of literature following this includes (Linnemann, 1966b; Wang and Winters, 1992; Raballand, 2003). This approach has also been challenged for being an ad hoc process and does not guarantee the underlying expected value.

This study has adopted approaches one and two together so that they can complement each other, first the sample selection is based on the countries with less gaps, but the sample period also took into consideration the period when most of the countries, especially African countries has number values in their observations leaving aside those years with missing values. In this way there were very few gaps which were taken care of by the second approach.

Otherwise some other literature resorted to some other approaches such as the use of the original multiplicative gravity equation, hence nonlinear estimation technique (see for example Coe and Hoffmaister (1999)). In this way, there was no need for $\log$ transformation process where observation with zero values would be problematic. Some other studies adopting linear estimation techniques have used Tobit estimation technique (Linders and De Groot, 2006).

\section{Empirical Model}

An examination of bilateral trade between African countries and the BRICs formed two ways trade flows, which makes two sets of estimation results. To be consistent with what is being measured; same model with same set of variables is used so as to obtain coherent test results. Below two models are presented, one is for the variables at level, and the second includes product variables (i.e. a product of variable data for importing country and exporting country). The study also includes a dummy variable for time fixed effects, thus a two way fixed effects (observing variations of time and panels).

Estimation model using variables at level: Exports, population, GDP per capita, bilateral exchange rate, domestic credit to private sector and distance variables are in natural logarithm. The rest of the variables are either presented as ratios or they are dummies, hence there was no necessity of converting them into natural logs. Mobile cellular subscriptions represents a percentage of the total subscriptions to public mobile telephone network services, arable land is a percentage of total land mass of a particular country.

Dummy variables include the rest of the variables, i.e. whether they are members of the World Trade Organisation or not ( $O$ if none of the pair countries is, 1 if one country in a pair is a member, 2 if both are members), landlocked measures whether countries belong to a landlocked countries ( $O$ if none is, 1 if one in the pair is, and 2 if both are), language indicates whether both countries have common official language or not. The model is presented as follows;

$\log \operatorname{EXP}_{i j t}=\beta_{o}+\beta_{i} \log \left(P O P N_{i t}\right)+\beta_{2} \log \left(P O P N_{j i}\right)+\beta_{s} \log \left(G D P p p_{i t}\right)+\beta_{i} \log \left(G D P p_{i t}\right)+\beta_{s} \log \left(E X C H_{i t}\right)+\beta_{6} \log \left(D I S T_{i j}\right)+$ $\beta_{i} \log \left(C R D P R_{i t}\right)+\beta_{s} \log \left(C R D P R_{j t}\right)+\beta_{9} M_{10 B I L_{i t}}+\beta_{10} M_{O B I L_{j t}}+\beta_{11} A R B L_{i}+\beta_{12} A R B L_{j}+\beta_{1 s} W T O_{i j}+\beta_{14} L A N D L_{i j}$ $+\beta_{15} L A N G_{i j}+\partial D+\eta_{i j t}$

Where;

$\beta=$ represents the coefficients of the variables

$\operatorname{logEXP} P_{j i t}=$ natural logarithm for Exports from country $i$ to $j$

$\log P O P N_{i l}=$ natural logarithm for Population of importing country

$\log P O P N_{j i}=$ natural logarithm for Population of exporting country

$\log G D P p p_{i t}=$ natural logarithm for GDP per capita of importing country

$\log G D P p p_{j t}=$ natural logarithm for GDP per capita of exporting country

$\log E X C H_{i j t}=$ natural logarithm for bilateral exchange rate

$\log D I S T_{i j}=$ Distance between exporting $(l)$ and importing $(j)$ country

$\log C R P R_{i t}=$ Credit to private sector for importing country

$\log C R P R_{j l}=$ Credit to private sector for exporting country

$M O B_{i t}=$ Mobile cellular subscriptions for importing country

$M O B_{j t}=$ Mobile cellular subscription for exporting country

$A R B L_{i}=$ Arable Land for importing country

$A R B L_{j}=$ Arable Land for exporting country

$W T O_{i j}=$ WTO membership

$L A N D L_{i j}=$ Landlocked $(1$ if one of the country in a pair is land locked, 2 if both are land locked)

$L A N G_{i j}=$ Common official language ( 1 if both countries use same official language)

$\partial D=$ is a vector of year dummies for the year 1982 through 2012 (the year dummy for the year 1981 is dropped)

$\eta_{i j t}=$ is the error term

Estimation model including product variables: This model uses the same variables as above, only that it includes some variables representing a product of two variables for importing and exporting country. The aim is to examine how simultaneously the two variables can influence the bilateral trade flows between the two parties. The variables in a product form include mobile cellular subscription, arable land, and credit to private sectors, population and GDP per capita.

$\log E X P_{i j t}=\beta_{o}+\beta_{l} \log \left(P O P N_{i j t}\right)+\beta_{2} \log \left(G D P_{i j t}\right)+\beta_{s} \log \left(E X C H_{i j t}\right)+\beta_{i} \log \left(D I S T_{i j}\right)+\beta_{s} \log \left(C R D P R_{i j t}\right)+\beta_{6} \log \left(\operatorname{MOBIL} L_{i j t}\right)+\beta_{7} \log (A R$

$\left.B L_{i j}\right)+\beta_{s} W T O_{i j}+\beta_{9} L A N D L_{i j}+\beta_{t o} L A N G_{i j}+\partial D+\eta_{i t}$

Where;

$\log P O P N_{i j t}=$ natural $\log$ for a product of population of importing and exporting country 
$\log G D P p p_{i j t}=$ natural $\log$ for a product of GDP per capita of importing and exporting country $\log C R P R_{i j t}=$ natural $\log$ for a product of credit to private sector for importing and exporting country

$\log M O B_{i j t}=$ anatural $\log$ for product of mobile cellular subscriptions for importing and exporting country

$\log A R B L_{i j}=$ natural $\log$ for a product of credit to arable land private sector for importing and exporting country

The rest of the variables are defined as above (model 5).

Since the panel data analysis is used in this study to examine the determinants of bilateral trade flows, whereas the sample contains several countries and a number of periods, there is a need also to test whether time fixed effects have a role on bilateral trade flows as well. Therefore a full set of $(\mathrm{T}-1)$ time dummies, one for each period but the first, is introduced. If these dummies are not included it may lead to omitted variable bias in the results. These dummies, are shift variables that take the value of one for all states in the reference years and zero in all the others. Moreover, after estimation regressions are obtained, a joint test is conducted to see if these dummies are jointly equal to zero or not. This is not included in any of the models above because it is a post estimation process by using a 'test varlist' command. If the year dummies are zero then time fixed effects have no influence on the bilateral trade flows. Thus it will be testing the null hypothesis: all years' coefficients are jointly equal to zero. Failing to reject the null hypothesis will mean that no time fixed effects are needed.

\section{Estimation Techniques}

The study uses a panel based approach following the criticisms over using cross section estimation, which is misspecification, because it cannot deal with bilateral heterogeneity present in the bilateral trade flows. With panel data approach heterogeneity issues are modelled by including country-pair individual effects (Serlenga and Shin, 2004). The essence of using panel data is to control for these individual specific effects that are possibly unobservable but may be correlated with other explanatory variables in the econometric model (Hausman and Taylor, 1981).

There are a number of panel estimation techniques; the traditional and commonly used estimation technique for the gravity model studies has been the Ordinary Least Squares (OLS) technique. However the use of OLS has been challenged because its implementation assumptions are not in line with the underlying theoretical models. It ignores the fact that there can be a correlation between explanatory variables and individual effects which are unobservable, hence resulting to coefficient estimates that are severely biased (Serlenga and Shin, 2004). It also fails to account for endogeneity and biasness resulting from omission of variables. The presence of these correlations excludes both OLS and GLS from being used as estimation methods in the estimation of parameters of this study as may yield biased and inconsistent estimates (Hausman and Taylor, 1981).

In such a situation, traditionally the option has been to go for an instrumental variable (IV) estimation technique. Thus in order to overcome this, the within estimator from analysis of covariance or fixed effects estimation technique has been used (Cornwell and Rupert, 1988). The estimator is designed particularly for analysing the impact of variables that vary over time, as it assumes that the time invariant variables are unique to the individual country hence not correlated with other individual country characteristics. Therefore, under this method all the individual effects in the sample are eliminated by transforming the data into deviations from individual means.

As a result of this procedure, the within-groups estimator also suffers from two imperative defects; one, during data transformation process, all the time invariant variables are eliminated hence their coefficients are not estimated, two, the within group estimator ignores variation across the individuals or countries included in the sample hence it is not fully efficient. Comparatively, the first defect seem to be more serious especially when the primary interest in the application of the estimator is attached to the unknown coefficient of time invariant variables such as the influence of country's historical past events, membership to regional trading groups or countries using the same official language in the gravity modelling. Leaving these variables un-estimated renders the study meaningless.

The time invariant variables are well estimated by the GLS Random effects model (partial pooling model). This is because under this technique the assumption is that variations across countries are assumed random and uncorrelated with the independent variable used in the model. Therefore while under the fixed effect model, the time invariant variables are absorbed by the intercept, this technique include time invariant variables as explanatory variables in the model because for this model the error term is assumed to be uncorrelated with explanatory variables. Thus for a perfect estimation, inclusion of all individual country characteristics is required which is normally not possible hence leading to the omitted variable bias in the specified model.

In their ground-breaking paper of 1981, Jery Hausman and William Taylor developed an alternative method that has been used with panel data to treat the problem of correlation between explanatory variables and the concealed individual specific effect. It is an IV estimator with neither of the two defects mentioned above as it employs several dimensions of panel data to overcome the correlation without any variables from outside the model (Egger, 2002). The HT makes use of time varying variables in two ways - to estimate their own coefficients as well as serving as instruments for endogenous time invariant variables, hence giving room for identification and efficient estimation of both time varying and time invariant coefficients.

It is therefore better than the within groups estimation technique as it is more efficient and it also produces coefficient estimates for time invariant variables. The possibility of the existence of a potential correlation between the unobservable individual specific effect and a subset of the exogenous variables cannot be denied (Serlenga and Shin, 2004; Rault et al., 2009). Since the presence unobservable individual effects and time invariant variables is unquestionable even in the estimation of the bilateral trade flows in the African countries, this paper uses the Hausman Taylor estimator.

Consider the following equation; 


$$
Y_{i t}=X_{i} \beta+Z_{i} \gamma+\alpha_{i}+\eta_{i t} \quad(i=1 \ldots, N ; t=1, \ldots, T)
$$

Where, $\beta$ and $\gamma$ are $k$ and $g$ vector coefficients associated with time varying (for this case GDPpp, POPN,EXCH, CRDPR and MOBIL) and time invariant observable variables (for this case DIST and ARBL) respectively. The disturbance $\eta_{i t}$ is assumed uncorrelated with the columns of $(\mathrm{X}, \mathrm{Z}, \alpha)$. The individual specific effects $\alpha_{i}$ (for this case LANDL, CONTIG, LANG and WTO) are assumed to be time invariant random variable and in this study is potentially correlated with columns of $X$ and $Z$.

The HT estimation model does not assume a specification of the unobservable individual specific effects $\alpha_{i}$ and it is less sensitive to whether they are known or unknown by the researcher (Hausman and Taylor, 1981). In this way handles the risk of falling into biased results due to omission of variables. It rather works under an assumption that some variables among $X$ and $Z$ are uncorrelated with individual specific effects $\alpha_{i}$. And that the $X_{i t}$ which are uncorrelated with $\alpha_{i}$ serves two functions because of their variation across both individuals and time; first, using deviations from individual means, they produce unbiased estimates of the coefficients, and secondly using the individual means, they produce valid instruments for the time invariant variables $\left(Z_{i}\right)$ that are correlated with the individual specific effects $\alpha_{i}$ (Hausman and Taylor, 1981). Therefore it helps to avoid the difficulty of extracting instrument variables external to the specified model by using some variables within the model as instruments.

However for comparison purposes as well as for checking the robustness of the results, HT estimation techniques will be used together with some other panel data estimation techniques including the random effect generalized least square regression and the fixed effect (within) estimation techniques.

\section{Gravity Model Estimation Results}

The estimation is done for model 5 and 6 and, for each model regressions are conducted twofold; the bilateral trade flows from African countries to the BRICS and, from the BRICs to African countries. Moreover, for each part estimation is done in two steps, in the first step variables are considered at level, while in the second step the model includes some variables as a product of the values of the two trading partners. Both models are estimated using the HT, estimation technique as well other two panel data estimators. Results are presented in Table 4 to 5.

From the results in Table 4 three major factors that influence the bilateral trade between Africa and the BRIC countries include the use of common official language, the GDP per capita and population. The variables are statistically significant and economically reasonable. Results in Table 5 reveals that, arable land and bilateral exchangerate are also important in explaining the bilateral trade flows between trading partners. And in both equations the time dummies are jointly highly significant.

Table-4. Empirical Results, Africa-BRIC bilateral trade flows (variables at level)

\begin{tabular}{|c|c|c|c|c|c|c|}
\hline \multirow[b]{2}{*}{ Modelling technique } & \multicolumn{3}{|c|}{ From Africa to the BRIC } & \multicolumn{3}{|c|}{ From the BRIC to Africa } \\
\hline & HT & RE & FE & HT & RE & FE \\
\hline $\operatorname{lnPopulation}_{i}$ & $\begin{array}{l}0.88 \\
(0.56)\end{array}$ & $\begin{array}{l}1.46^{* * * *} \\
(0.14)\end{array}$ & $\begin{array}{l}1.59^{* * * *} \\
(0.63)\end{array}$ & $\begin{array}{l}3.59 * * * \\
(0.27)\end{array}$ & $\begin{array}{l}2.55^{* * * *} \\
(0.12)\end{array}$ & $\begin{array}{l}3.86^{* * * *} \\
(0.38)\end{array}$ \\
\hline lnPopulation $_{j}$ & $\begin{array}{l}3.32^{* * * *} \\
0.83\end{array}$ & $\begin{array}{l}2.27 * * * \\
(0.32)\end{array}$ & $\begin{array}{l}1.42 \\
(0.95)\end{array}$ & $\begin{array}{l}1.90^{* * * *} \\
(0.21)\end{array}$ & $\begin{array}{l}1.19^{* * * *} \\
(0.06)\end{array}$ & $\begin{array}{l}1.81^{* * * *} \\
(0.26)\end{array}$ \\
\hline lnDistance $_{i j}$ & $\begin{array}{l}-3.89 \\
(6.19)\end{array}$ & $\begin{array}{l}1.04 \\
(0.78)\end{array}$ & - & $\begin{array}{l}4.77 * * \\
(2.21)\end{array}$ & $\begin{array}{l}-0.32 \\
(0.29)\end{array}$ & - \\
\hline $\operatorname{lnGDP}$ per capita ${ }_{i}$ & $\begin{array}{l}1.96^{* * * *} \\
(0.23)\end{array}$ & $\begin{array}{l}1.57^{* * * *} \\
(0.17)\end{array}$ & $\begin{array}{l}2.07 * * * \\
(0.24)\end{array}$ & $\begin{array}{l}0.71 * * * \\
(0.07)\end{array}$ & $\begin{array}{l}1.14^{* * * *} \\
(0.05)\end{array}$ & $\begin{array}{l}0.73^{* * * *} \\
(0.07)\end{array}$ \\
\hline lnGDP per capita & $\begin{array}{l}1.28^{* * * *} \\
(0.19)\end{array}$ & $\begin{array}{l}1.39^{* * * *} \\
(0.14)\end{array}$ & $\begin{array}{l}1.46^{* * * *} \\
(0.19)\end{array}$ & $\begin{array}{l}0.87^{* * *} * \\
(0.07)\end{array}$ & $\begin{array}{l}0.76^{* * * *} \\
(0.06)\end{array}$ & $\begin{array}{l}0.73^{*} * * \\
(0.08)\end{array}$ \\
\hline lnCredit to Private Sector $i$ & $\begin{array}{l}-0.12 \\
(0.11)\end{array}$ & $\begin{array}{l}-0.41^{*} \\
(0.22)\end{array}$ & $\begin{array}{l}-0.24 \\
(0.23)\end{array}$ & $\begin{array}{l}-0.28^{* * * *} \\
(0.06)\end{array}$ & $\begin{array}{l}0.01 \\
(0.03)\end{array}$ & $\begin{array}{l}0.01 \\
(0.04)\end{array}$ \\
\hline lnCredit to Private Sector ${ }_{j}$ & $\begin{array}{l}-0.39^{*} \\
(0.21)\end{array}$ & $\begin{array}{l}-0.02 \\
(0.11)\end{array}$ & $\begin{array}{l}-0.03 \\
(0.11)\end{array}$ & $\begin{array}{l}-0.01 \\
(0.03)\end{array}$ & $\begin{array}{l}-0.29^{* * * *} \\
(0.07)\end{array}$ & $\begin{array}{l}-0.19 * * * \\
(0.07)\end{array}$ \\
\hline InBilateral Exchange Rate ${ }_{i j}$ & $\begin{array}{l}-0.02 \\
(0.03)\end{array}$ & $\begin{array}{l}-0.02 \\
(0.03)\end{array}$ & $\begin{array}{l}-0.02 \\
(0.04)\end{array}$ & $\begin{array}{l}-0.04 * * * * \\
(0.00)\end{array}$ & $\begin{array}{l}-0.03 * * * \\
(0.00)\end{array}$ & $\begin{array}{l}-0.05^{* * * *} \\
(0.01)\end{array}$ \\
\hline Mobile Cellular $_{i}$ & $\begin{array}{l}0.01^{*} \\
(0.00)\end{array}$ & $\begin{array}{l}-0.00 \\
(0.00)\end{array}$ & $\begin{array}{l}-0.01 \\
(0.00)\end{array}$ & $\begin{array}{l}0.01^{* * * *} \\
(0.00\end{array}$ & $\begin{array}{l}0.01^{* * * *} \\
(0.00)\end{array}$ & $\begin{array}{l}0.01^{* * * *} \\
(0.00)\end{array}$ \\
\hline Mobile Cellular $_{j}$ & $\begin{array}{l}0.01 \\
(0.00)\end{array}$ & $\begin{array}{l}0.01^{* * * *} \\
(0.00)\end{array}$ & $\begin{array}{l}0.01^{* * * *} \\
(0.00)\end{array}$ & $\begin{array}{l}0.01^{* * * *} \\
(0.00\end{array}$ & $\begin{array}{l}0.01^{* * * *} \\
(0.00)\end{array}$ & $\begin{array}{l}0.01 * * * \\
(0.00)\end{array}$ \\
\hline Arable land $_{i}$ & $\begin{array}{l}0.03 \\
(0.01)\end{array}$ & $\begin{array}{l}0.00 \\
(0.01)\end{array}$ & - & $\begin{array}{l}-0.12^{* * * *} \\
(0.01)\end{array}$ & $\begin{array}{l}0.01 \\
(0.01)\end{array}$ & - \\
\hline Arable land $_{j}$ & $\begin{array}{l}-0.25^{* * *} \\
(0.04)\end{array}$ & $\begin{array}{l}0.01 \\
(0.01)\end{array}$ & - & $\begin{array}{l}-0.01 \\
(0.00)\end{array}$ & $\begin{array}{l}-0.03 * * * \\
(0.01)\end{array}$ & - \\
\hline Landlocked & $\begin{array}{l}-0.41 \\
(2.77)\end{array}$ & $\begin{array}{l}-0.63 \\
(0.52) \\
\end{array}$ & - & $\begin{array}{l}-1.26^{*} \\
(0.76)\end{array}$ & $\begin{array}{l}-1.57^{* * * *} \\
(0.22)\end{array}$ & - \\
\hline Common language official & $\begin{array}{l}7.05^{*} \\
(3.80) \\
\end{array}$ & $\begin{array}{l}0.39 \\
(0.71) \\
\end{array}$ & - & $\begin{array}{l}2.67 * * * \\
(1.10)\end{array}$ & $\begin{array}{l}1.33^{* * * *} \\
(0.33)\end{array}$ & - \\
\hline WTO membership & $\begin{array}{l}0.68 \\
(2.85)\end{array}$ & $\begin{array}{l}-0.03 \\
(0.55)\end{array}$ & - & $\begin{array}{l}-0.54 \\
(0.93)\end{array}$ & $\begin{array}{l}-0.19 \\
(0.26)\end{array}$ & - \\
\hline Year dummy & $\begin{array}{l}83.46^{* * * *} \\
(0.00)\end{array}$ & $\begin{array}{l}85.84^{* * * *} \\
(0.00)\end{array}$ & $\begin{array}{l}3.63^{* * * *} \\
(0.00) \\
\end{array}$ & $\begin{array}{l}41.14^{* * * *} \\
(0.01)\end{array}$ & $\begin{array}{l}46.19^{* * *} \\
(0.00)\end{array}$ & $\begin{array}{l}1.63^{* *} \\
(0.05)\end{array}$ \\
\hline R-square & - & 0.45 & 0.34 & - & 0.66 & 0.46 \\
\hline No. of observations & 2,321 & 2,321 & 2,321 & 3,778 & 3,778 & 3,778 \\
\hline No of country pairs & 148 & 148 & 148 & 164 & 164 & 164 \\
\hline
\end{tabular}

Note: The dependent variable for these regression results exports from country $i$ to $j$. *******, * denotes significance level at $1 \%, 5 \%$ and $10 \%$ respectively Standard errors are in parentheses. $i$ denotes exporting country, while $j$ denotes importing county. Under the Hausman - Taylor modelling technique all the time varying variables are used as instruments for endogenous time invariant variables. 
The variable common official language has higher coefficients than the rest of the variables more so in Table 4 . The coefficients are positive and statistically significant implying that the bilateral trade between African countries and the BRIC is explained by use of common official language. However in actual sense there is no African country that uses Chinese or any of the Russian language as an official language. But the fact that English is adopted by many countries as a medium of business language it has become possible for trade with China as well.

GDP per capita variables has positive and statistically significant coefficients in most cases at one per cent level. Except for the fixed effects estimations on the variables at level in Table 4, the coefficients are not significant in both cases. This is applicable for both the exporting and the importing country which indicates that the level of economic development tends to positively influence the exports and imports in the bilateral trade between Africa and the BRIC countries. As explained earlier in this study, the BRIC-Africa trade is characterised by the exports of primary commodities from African countries and importation of food and consumables from BRIC countries, but mainly from China. This is a vivid complementarily, whereas African exports feeds the growing industries in the BRICs African countries also imports manufactured goods from these countries, particularly from China. The imported manufactured goods are not only for household consumption but also for feeding the growing manufacturing sector in the African countries (Broadman, 2006).

It is also worth noting that African countries where most of this bilateral trade with BRIC is concentrated includes those countries which are rich in natural resources, and in most cases they are the same with higher GDP per capita among the African countries. Thus, an automatic connection with the role of the level of economic development with the bilateral trade. These results are similar to the claim by Markusen that the intra-country distribution of income measured by GDP per capita matters for inter-country trade (Markusen, 2013). Besides Deardorff (2011) confirms that economies with higher per capita income are expected to have high capital labour ratios which results into producing more of capital intensive goods and will tend to trade more because they produce more and consume larger proportions of capital-intensive goods. Recent literature concludes that there is robust empirical evidence that economies with lower per capita income will tend to have smaller volumes of bilateral trade even after controlling for aggregate income (Tarasov, 2012). Likewise he asserts that not only trade volume will be lower but also less number of trading partners can be expected for such economies.

In their seminal paper examining the North - South trade, Coe and Hoffmaister (1999) assert that income has a positive impact of bilateral trade such that a 1 percent increase in income of the trading partners, will lead to an increase in the bilateral trade between the two groups by 2 per cent. These results are somehow similar to what this paper presents in Table 4 as well as Table 5.

\begin{tabular}{|c|c|c|c|c|c|c|}
\hline \multirow[b]{2}{*}{ Modelling technique: } & \multicolumn{3}{|c|}{ From Africa to the BRIC } & \multicolumn{3}{|c|}{ From the BRIC to Africa } \\
\hline & HT & RE & FE & HT & RE & FE \\
\hline $\ln \left(\right.$ Mobilecellular $\left._{i} x_{j}\right)$ & $\begin{array}{l}-0.01 \\
(0.02) \\
\end{array}$ & $\begin{array}{l}0.02 \\
(0.01)\end{array}$ & $\begin{array}{l}0.03 \\
(0.02) \\
\end{array}$ & $\begin{array}{l}0.05^{* * *} \\
(0.00)\end{array}$ & $\begin{array}{l}0.07 * * * \\
(0.01)\end{array}$ & $\begin{array}{l}-0.01 \\
(0.01) \\
\end{array}$ \\
\hline $\ln \left(\right.$ Arable land $\left.x_{j}\right)$ & $\begin{array}{l}0.11 \\
(0.22) \\
\end{array}$ & $\begin{array}{l}0.24^{*} \\
(0.14) \\
\end{array}$ & - & $\begin{array}{l}0.65^{* * *} \\
(0.14)\end{array}$ & $\begin{array}{l}0.05^{* * *} \\
(0.01)\end{array}$ & - \\
\hline $\ln \left(\right.$ Credit to Privat.i $\left.x_{j}\right)$ & $\begin{array}{l}-0.05 \\
(0.10)\end{array}$ & $\begin{array}{l}0.02 \\
(0.10)\end{array}$ & $\begin{array}{l}0.04 \\
(0.01)\end{array}$ & $\begin{array}{l}-0.05 \\
(0.08)\end{array}$ & $\begin{array}{l}0.14 \\
(0.13) \\
\end{array}$ & $\begin{array}{l}0.20 \\
(0.14)\end{array}$ \\
\hline lnExchange rate & $\begin{array}{l}-0.34 * * * \\
(0.07)\end{array}$ & $\begin{array}{l}-0.30^{* * * *} \\
(0.07)\end{array}$ & $\begin{array}{l}-0.36^{* * *} \\
(0.07)\end{array}$ & $\begin{array}{l}-0.07 * * * \\
(0.01)\end{array}$ & $\begin{array}{l}-0.07 * * * * \\
(0.02)\end{array}$ & $\begin{array}{l}-0.04 \\
(0.02)\end{array}$ \\
\hline $\ln \left(\right.$ Population $\left._{i} x_{j}\right)$ & $\begin{array}{l}0.08^{* * *} * \\
(0.01)\end{array}$ & $\begin{array}{l}\text { O.09*** } \\
(0.01)\end{array}$ & $\begin{array}{l}0.11^{* * *} \\
(0.03)\end{array}$ & $\begin{array}{l}0.09^{* * *} * \\
(0.00)\end{array}$ & $\begin{array}{l}0.08^{* * *} * \\
(0.00)\end{array}$ & $\begin{array}{l}0.18^{* * * *} \\
(0.02)\end{array}$ \\
\hline $\ln \left(\right.$ GDPpp $\left.i x_{j}\right)$ & $\begin{array}{l}0.29 * * * \\
(0.02)\end{array}$ & $\begin{array}{l}0.22^{* * *} \\
(0.02)\end{array}$ & $\begin{array}{l}0.31^{* * *} * \\
(0.03)\end{array}$ & $\begin{array}{l}0.19^{* * *} \\
(0.01)\end{array}$ & $\begin{array}{l}0.12^{* * *} \\
(0.01)\end{array}$ & $\begin{array}{l}0.19^{* * * *} \\
(0.02)\end{array}$ \\
\hline lnDistance & $\begin{array}{l}11.47^{* * * * *} \\
(4.74)\end{array}$ & $\begin{array}{l}2.12^{* * * *} \\
(0.69)\end{array}$ & - & $\begin{array}{l}1.12 \\
(2.28)\end{array}$ & $\begin{array}{l}-0.42 \\
(0.39)\end{array}$ & - \\
\hline Landlocked & $\begin{array}{l}-0.82 \\
(0.90)\end{array}$ & $\begin{array}{l}-0.99^{*} \\
(0.56)\end{array}$ & - & $\begin{array}{l}-1.09^{* * * *} \\
(0.45)\end{array}$ & $\begin{array}{l}-1.31^{* * * *} \\
(0.29)\end{array}$ & - \\
\hline Common Official Language & $\begin{array}{l}3.59^{* * * *} \\
(1.36)\end{array}$ & $\begin{array}{l}1.63^{* * * *} \\
(0.72)\end{array}$ & - & $\begin{array}{l}-0.26 \\
(0.69)\end{array}$ & $\begin{array}{l}0.43 \\
(0.41)\end{array}$ & - \\
\hline WTO membership & $\begin{array}{l}0.39 \\
(1.01)\end{array}$ & $\begin{array}{l}-0.49 \\
(0.58)\end{array}$ & - & $\begin{array}{l}-0.07 \\
(0.61)\end{array}$ & $\begin{array}{l}-0.36 \\
(0.37)\end{array}$ & - \\
\hline Years & $\begin{array}{l}95.74^{* * * *} \\
(0.00)\end{array}$ & $\begin{array}{l}117.85^{* * *} * \\
(0.00)\end{array}$ & $\begin{array}{l}5.43 * * * \\
(0.00)\end{array}$ & $\begin{array}{l}36.18^{* * * *} \\
(0.00)\end{array}$ & $\begin{array}{l}33.19^{* *} \\
(0.02)\end{array}$ & $\begin{array}{l}1.94 * * * * \\
(0.01)\end{array}$ \\
\hline R-square & & 0.41 & 0.23 & & 0.62 & 0.54 \\
\hline No. of observations & 1,818 & 1,818 & 1,818 & 2,454 & 1,654 & 1,654 \\
\hline No. of country pairs & 148 & 148 & 148 & 164 & 128 & 128 \\
\hline
\end{tabular}

Note: The dependent variable for these regression results exports from country $i$ to $j$.***, ***, denotes significance level at $1 \%, 5 \%$ and $10 \%$ respectively Standard errors are in parentheses. $i$ denotes exporting country, while $j$ denotes importing county. Under the Hausman -Taylor modelling technique all the time varying variables are used as instruments for endogenous time invariant variables.

Population variable has positive and significant coefficients especially in the bilateral trade from BRIC countries to Africa. This imply that an increase in population tend to result into a proportionate increase in trade between trading partners. For the trade flow from Africa to BRIC, the coefficient does not support that the increase in population leads to an increase in exports but more in imports. However the literature assert that there has been an increase in the food exports from Africa to Asian countries particularly China and India, and this has been as a result of an increasing populations and income levels in these countries (Broadman, 2006). This fact is confirmed by the results in Table 5 when population is used as a product variable, the coefficient turn to be positive and significant.

Moreover, the flow of manufactured goods from BRIC countries to African countries are for the search of market, and data shows that Nigeria, which is the most populous country in the continent records higher imports from China (WB, 2014). The African exports concentration is also based on the same pattern, for the period 
between 2000 to 2004 more than 80 percent of value added exports from Africa originated from Nigeria (refined petroleum), South Africa (refined petroleum products, pharmaceuticals, electronics, machinery and transportation equipment's) and Swaziland (pharmaceuticals) (Broadman, 2006).

Bilateral exchange rate has negative coefficients though not significant in all estimation techniques for the variables at level. The effects of bilateral exchange rate on bilateral trade arises where there are uncertainties on the appreciation and depreciation in value of any of the trading partner's currency. This exchange rate volatility has a tendency of affecting the profitability of foreign exchange trades. The coefficients for the variable are negative and significant especially with results in Table 5. The results signify that in times when the bilateral exchange rate index drops, the exporter currency depreciates with respect to the trading partner's currency, which improves the exports competitiveness (Rault et al., 2009; Iqbal and Islam, 2014). Generally these results provide coefficients that confirm that bilateral exchange rate changes adversely affect the bilateral trade flows between trading partners. De Vita and Abbott (2004) confirms the negative effect that exchange rate uncertainty has on export volumes, in his study exchange rate uncertainty is found to have negative and significant influence on the UK exports to the EU countries. The argument is, despite the fact that with short run fluctuations hedging can be used to insure the risk, it becomes more challenging to cover against long-term exchange rate fluctuations.

These results are also supported by Iqbal and Islam (2014) who asserts that the bilateral real exchange rates are inversely related to the bilateral trade flow between Bangladesh and the European Union. Besides, the negative coefficients conforms to the results by Chowdhury (1993) whose error-correction results indicate that exchange rate volatility has a significant negative impact on the volume of exports in each of the G-7 countries. Moreover, Rault et al. (2009) modelling trade flows between CEEC and OECD countries get the same results implying that when exchange rate index slumps the exporter currency depreciates relative to the currency of the importer, hence improving export competitiveness.

The coefficients for the distance variable also do not appear to have consistent sign and significance in all the estimation techniques. However, the traditional gravity model studies and many recent empirical studies find that the level of trade between a pair of countries is a negative function of the distance between trading pair countries (Rose and Van Wincoop, 2001; Tripathi and Leitão, 2013). Hence the inconsistence in these results could possibly be insinuating the aspect of the death of distance due to technological advancement in the transportation and communication sectors as discussed earlier in this paper.

A country in a trading pair being a member to WTO or not has also been examined, in the estimation results under the Hausman Taylor, coefficients are positive but not significant in both cases. However looking of the rest of the estimation techniques, they give mixed results. This could be in line with what is discussed in the literature, while Rose (2004) suggest that membership to WTO does not have any positive effects on trade, Subramanian and Wei have provided evidence that though little but there is an impact of WTO membership on bilateral trade. They find that bilateral trade is greater when both partners had liberalized their trade policy than when only one partner did and the other did not. Besides, as it is in theory, the WTO membership impact would depend on what the country does with its membership, with whom it negotiates, and which products the negotiation covers. This disagreement might explain the mixed regression results in this study (Subramanian and Wei, 2007).

The variable arable land does not give out the expected results. When the variable is estimated at level it almost gives negative coefficients, but the coefficients becomes positive when tested as a product variable. The coefficients takes a positive sign with high statistical significance for the trade flow from BRIC to Africa; and it indicate that the size arable land tend to statistically explain 65 per cent of the variations on exports for the bilateral trade flow from the BRIC to African countries. The coefficients for the variable land locked are negative but not significant in all the estimation techniques, however it implies that the variable has a good explanatory power on the bilateral trade between the Africa and the BRIC countries.

The coefficient for the variable credit to private sector does not indicate the expected results. The coefficients are negative and in most cases not significant, hence reflecting that the variable does not explain the bilateral trade flows between African countries and the BRIC countries. This could be resulting from the nature of the African private sector and enterprises which are characterised with low level of innovation capabilities and competitiveness (UNCTAD, 2013). They thus do not have significant contribution to the competitiveness of the products to the market external to Africa.

Looking at the results in Table 4 and 5, the coefficients for the mobile cellular variable seem to indicate that the variable affect the trade from BRIC to Africa positively. The coefficients are positive and significant. However the magnitude of the effects on trade is so minimal around 0.1 to 0.7 per cent for any 10 percent increase in mobile cellular subscriptions. All the same this shows that the mobile phone usages do have an impact in enhancing the linkage between trading partners.

\section{Conclusion}

The paper examines the determinants for the bilateral trade flows of bilateral trade flow between Africa and BRIC using the gravity model on some economic, demographic, cultural and political ties data of the African countries and their trading partners. It has included some new variables in the gravity model considering their pivotal role particularly in the Africa trading activities. Considering the role of private sector in the bilateral trade, credit to private sector was also included in modelling African bilateral trade flows. Besides the fact that the continent account for a significant portion of the world arable land (27\%), arable land was also included to consider the role of productivity on bilateral trade. In the recent decade, mobile phones has become widely used particularly in the African countries, measured by a number of subscriptions for each country, mobile phone usage has also been included to examine its role in the augmentation of bilateral trade flows. All of these variables have indicated that they account for the bilateral trade in the African countries to a considerable extent, especially credit to private sector. Mobile phones usage also has a great potential to enhance the bilateral trade volumes of the African countries as well considering the limited infrastructural setup in the continent. But the sustainability and efficiency of this to happen will largely depend on the institutional climate and regulatory system in these economies to support these initiatives. 
The paper highlights some important facts that developing land locked countries trade less than their counter part developed land locked countries. Efficiency transportation and telecommunication systems in these countries makes landlocked-ness and distance to be less of a stumbling block to bilateral trade than it is for developing landlocked countries in Africa. Moreover, it highlights some important implications on the up surging trade links of Africa with emerging economies (BRIC). Data shows that the commodity composition of this bilateral trade is much concentrated on the primary products, and most especially on minerals and fuel products. Raising doubt on whether the growing bilateral trade with these countries is for the interest of either trading partners or it is for their benefit in order to feed their growing industrializing economies and leaving Africa a looser. Even looking at the main African countries that are leading for exportations in the BRIC countries, it is mainly the countries with large deposits of fuel and minerals like Angola, Algeria, South Africa and Nigeria to mention few, that has more trade volumes. Policy makers in the African countries should beware of the investment contracts and negotiations with these emerging countries so that the continent does not end loosing.

The bilateral trade flow between African countries and the BRIC countries is determined mainly by the GDP per capita, common official language and population. The empirical results show that even the size of arable land matters for this trade relationship. Still landlocked and distance poses a sizable negative influence on the volume of bilateral trade flow even between the African countries and the BRICs. Furthermore, it is anticipated that future research work examines the statistical determinants of African regional blocks and the RECs bilateral trade with the BRIC and the OECD. This is vital considering the regional diversity of Africa as far as trade and economic size is concerned.

\section{References}

Anderson, J.E., 1979. A theoretical foundation for the gravity equation. The American Economic Review, 69(1): 106-116.

Baier, S.L. and J.H. Bergstrand, 1997. International trade, regional free trade agreements, and economic development. Review of Development Economics, 1(2): 153-170. Available at: https://doi.org/10.1111/1467-9361.00011.

Baier, S.L. and J.H. Bergstrand, 2001. The growth of world trade: Tariffs, transport costs, and income similarity. Journal of International Economics, 53(1): 1-27. Available at: https://doi.org/10.1016/s0022-1996(00)00060-x.

Balassa, B., 1966. Tariff reductions and trade in manufacturers among the industrial countries. The American Economic Review, 56(3): 466473 .

Baldwin, R. and D. Taglioni, 2011. Gravity chains: Estimating bilateral trade flows when parts and components trade is important (No. w 16672). National Bureau of Economic Research.

Baltagi, B.H., P. Egger and M. Pfaffermayr, 2003. A generalized design for bilateral trade flow models. Economics Letters, 80(3): 391-397. Available at: https://doi.org/10.1016/s0165-1765(03)00115-0.

Baltagi, B.H. and C. Kao, 2000. Nonstationary panels, cointegration in panels and dynamic panels: A survey. Advances in Econometrics, 15: $7-51$.

Baxter, M. and M.A. Kouparitsas, 2006. What determines bilateral trade flows? (No. w 12188). National Bureau of Economic Research.

BBC News Business, 2014. Available from http://www.bbc.co.uk/news/business-26913497 [Accessed June 30, 2014$].$

Bikker, J.A., 1987. An international trade flow model with substitution: An extension of the gravity model. Kyklos, 40(3): 31 5-337. Available at: https://doi.org/10.1111/j.1467-6435.1987.tbo0683.x.

Broadman, H.G., 2006. Africa's Silk road: China and India's new economic frontier. The World Bank.

Cairncross, F., 2001. The death of distance: How the communications revolution is changing. Cambridge, MA: Harvard Business School Publishing.

Capling, A. and K.R. Nossal, 2001. Death of distance or tyranny of distance? The Internet, deterritorialization, and the anti-globalization movement in Australia. The Pacific Review, 14(3): 443-465. Available at: https://doi.org/10.1080/09512740126821.

Chowdhury, A., 1993. Does exchange rate volatility depress trade flows? Evidence from error-correction models. The Review of Economics and Statistics, 75(4): 700-706. Available at: https://doi.org/10.2307/21 10025.

Coe, D.T. and A.W. Hoffmaister, 1999. North-South trade: Is Africa unusual? Journal of African Economies, 8(2): 228-256. Available at: https://doi.org/10.1093/jae/8.2.228.

Cornwell, C. and P. Rupert, 1988. Efficient estimation with panel data: An empirical comparison of instrumental variables estimators. Journal of Applied Econometrics, 3(2): 149-155. Available at: https://doi.org/10.1002/jae.3950030206.

Coulibaly, S. and L. Fontagné, 2006. South-South trade: Geography matters. Journal of African Economies, 15(2): 313-341. Available at: https://doi.org/10.1093/jae/ejio3o.

De Castro, T., 2012. Trade cooperation indicators: Development of BRIC bilateral trade flows. International Review of Business Research Papers, 8(1): 211-223.

De Grauwe, P., R. Houssa and G. Piccillo, 2012. African trade dynamics: Is China a different trading partner? Journal of Chinese Economic and Business Studies, 10(1): 15-45. Available at: https://doi.org/10.1080/14765284.2012.638460.

De Vita, G. and A. Abbott, 2004. The impact of exchange rate volatility on UK exports to EU countries. Scottish Journal of Political Economy, 51(1): 62-81. Available at: https://doi.org/10.1111/j.0036-9292.2004.05101004.x.

Deardorff, A.V., 2011. Determinants of bilateral trade: does gravity work in a neoclassical world?. In Comparative Advantage, Growth, and the Gains From Trade and Globalization: A Festschrift in Honor of Alan V Deardorff. pp: 267-293.

Drummond, M.P. and M.E.X. Liu, 2013. Africa's rising exposure to China: How large are spillovers through trade? International Monetary Fund Working Paper.

Drysdale, P. and R. Garnaut, 1982. Trade intensities and the analysis of bilateral trade flows in a many-country world: A survey. Hitotsubashi Journal of Economics, 22(2): 62-84.

Egger, P., 2002. An econometric view on the estimation of gravity models and the calculation of trade potentials. World Economy, 25(2): 297-312. Available at: https://doi.org/10.1111/1467-9701.00432.

Eichengreen, B. and D.A. Irwin, 1998. The role of history in bilateral trade flows. In The regionalization of the world economy. University of Chicago Press. pp: 33-62.

Evenett, S.J. and W. Keller, 2002. On theories explaining the success of the gravity equation. Journal of Political Economy, 110(2): $281-316$. Available at: https://doi.org/10.1086/338746.

Feenstra, R.C., J.R. Markusen and A.K. Rose, 2001. Using the gravity equation to differentiate among alternative theories of trade. Canadian Journal of Economics, 34(2): 430-447. Available at: https://doi.org/10.1111/0008-4085.00082.

Fontagné, L. and M. Freudenberg, 2002. Long-term trends in intra-industry trade. In Frontiers of Research in Intra-Industry Trade. London: Palgrave Macmillan. pp: 131-158.

Foroutan, F. and L. Pritchett, 1993. Intra-Sub-Saharan African trade: is it too little?. Journal of African Economies, 2(1): 74-105. Available at: https://doi.org/10.1093/oxfordjournals.jae.a036775.

Frankel, J. and A. Rose, 2002. An estimate of the effect of common currencies on trade and income. The Quarterly Journal of Economics, $117(2)$ : 437-466. Available at: https://doi.org/10.1162/003355302753650292.

Frankel, J., E. Stein and S.-J. Wei, 1995. Trading blocs and the Americas: The natural, the unnatural, and the super-natural. Journal of Development Economics, 47(1): 61-95. Available at: https://doi.org/10.1016/0304-3878(95)00005-4.

Frankel, J.A., E. Stein and S.J. Wei, 1997. Regional trading blocs in the world economic system. Peterson Institute.

Frankel, J.A. and S.J. Wei, 1998. Regionalization of world trade and currencies: Economics and politics. In The regionalization of the world economy. University of Chicago Press. pp: 189-226. 
Guttmann, S. and A. Richards, 2006. Trade openness: An Australian perspective. Australian Economic Papers, 45(3): 188-203. Available at: https://doi.org/10.1111/j.1467-8454.2006.00287.x.

Hausman, J.A. and W.E. Taylor, 1981. Panel data and unobservable individual effects. Econometrica, 49(6): 1377-1398. Available at: https://doi.org/10.2307/1911406.

Haveman, J. and D. Hummels, 2004. Alternative hypotheses and the volume of trade: The gravity equation and the extent of specialization. Canadian Journal of Economics, 37(1): 199-218. Available at: ttps://doi.org/10.1111/j.0008-4085.2004.011_1.x.

Hummels, D., 2007. Transportation costs and international trade in the second era of globalization. Journal of Economic Perspectives, $21(3)$ : 131-154. Available at: https://doi.org/10.1257/jep.21.3.131.

Hummels, D. and J. Levinsohn, 1995. Monopolistic competition and international trade: Reconsidering the evidence. The Quarterly Journal of Economics, $110(3)$ : 799-836. Available at: https://doi.org/10.2307/2946700.

Iqbal, M.H. and A.F. Islam, 2014. Determinants of bilateral trade between Bangladesh and the European Union: Approach of gravity model under the panel data. Issues in Business Management and Economics, 2(5): 087-093.

Islam, A., H. Bloch and R. Salim, 2014. How effective is the free trade agreement in South Asia? An empirical investigation. International Review of Applied Economics, 28(5): 611-627. Available at: https://doi.org/10.1080/02692171.2014.918940.

Kimino, S., D.S. Saal and N. Driffield, 2007. Macro determinants of FDI inflows to Japan: An analysis of source country characteristics. World Economy, 30(3): 446-469. Available at: https://doi.org/10.1111/j.1467-9701.2007.01001.x.

Kolko, J., 2000. The death of cities? The death of distance? Evidence from the geography of commercial Internet usage. In vogelsang, Ingo and compaine, Benjamin (Eds), The internet upheaval: Raising questions, seeking answers in communications policy. Cambridge, MA: MIT Press. pp: 73-98.

Krugman, P., 1995. Increasing returns, imperfect competition and the positive theory of international trade. Handbook of International Economics, 3: 1243-1277. Available at: https://doi.org/10.1016/s1573-4404(05)80004-8.

Krugman, P.R., 1979. Increasing returns, monopolistic competition, and international trade. Journal of International Economics, 9(4): 469479. Available at: https://doi.org/10.1016/0022-1996(79)90017-5.

Krugman, P.R. and H. Elhanan, 1985. Market structure and foreign trade: Increasing returns, imperfect competition, and the international economy. 11-29.

Linders, G.J.M. and H.L. De Groot, 2006. Estimation of the gravity equation in the presence of zero flows (No. 06-072/3). Tinbergen Institute.

Linnemann, H., 1966a. An econometric study of international trade flows. Amsterdam: North-Holland Publishing Company.

Linnemann, H., 1966b. An econometric study of international trade flows. Netherlands School of Economics.

Markusen, J.R., 2013. Putting per-capita income back into trade theory. Journal of International Economics, 90(2): 255-265. Available at: https://doi.org/10.1016/j.jinteco.2013.04.003.

Martin, W. and C.S. Pham, 2015. Estimating the gravity model when zero trade flows are frequent and economically determined. The World Bank.

Musila, J.W. and S.P. Sigué, 2010. Corruption and international trade: An empirical investigation of african countries. World Economy, 33(1): 129-146. Available at: https://doi.org/10.1111/j.1467-9701.2009.01208.x.

Raballand, G., 2003. Determinants of the negative impact of being landlocked on trade: An empirical investigation through the Central Asian case. Comparative Economic Sudies, 45(4): 520-536. Available at: https://doi.org/10.1057/palgrave.ces.8100031.

Rault, C., R. Sova and A.M. Sova, 2009. Modelling international trade flows between CEEC and OECD countries. Applied Economics Letters, 16(15): 1547-1554. Available at: https://doi.org/10.1080/13504850701564330.

Rose, A.K., 1991. Why has trade grown faster than income? Canadian Journal of Economics, 24(2): 417-427. Available at: https://doi.org/10.2307/135631.

Rose, A.K., 2004. Do WTO members have more liberal trade policy?. Journal of International Economics, 63(2): 209-235. Available at: https://doi.org/10.1016/s0022-1996(03)00071-0.

Rose, A.K. and E. Van Wincoop, 2001. National money as a barrier to international trade: The real case for currency union. American Economic Review, 91(2): 386-390. Available at: https://doi.org/10.1257/aer.91.2.386.

Sanso, M., R. Cuairan and F. Sanz, 1993. Bilateral trade flows, the gravity equation, and functional form. The Review of Economics and Statistics, $75(2):$ 266-275. Available at: https://doi.org/10.2307/2109432.

Serlenga, L. and Y. Shin, 2004. Gravity models of the intra-EU trade: Application of the Hausman-Taylor estimation in heterogeneous panels with common time-specific factors. Mimeo: University of Edinburgh.

Shinyekwa, I. and O. Lawrence, 2013. Comparing the performance of Uganda's Intra-East African community trade and other trading blocs: A gravity model analysis (No. 159667).

Sichei, M., J.-L. Erero and T. Gebreselasie, 2011. An augmented gravity model of South Africa's exports of motor vehicles, parts and accessories. South African Journal of Economic and Management Sciences, 11(4): 494-510. Available at: https://doi.org/10.4102/sajems.v 11 iit.284.

Subramanian, A. and S.-J. Wei, 2007. The WTO promotes trade, strongly but unevenly. Journal of International Economics, 72(1): 151-175. Available at: https://doi.org/10.1016/j.jinteco.2006.07.007.

Tansey, M.M. and A. Touray, 2010. The gravity model of trade applied to Africa. The International Business \& Economics Research Journal, 9(3): 127-130. Available at: https://doi.org/10.19030/iber.v9i3.543.

Tarasov, A., 2012. Per capita income, market access costs, and trade volumes. Journal of International Economics, 86(2): 284-294. Available at: https://doi.org/10.1016/j.jinteco.2011.10.006.

Tinbergen, J., 1962. Shaping the world economy: Suggestions for an international economic policy. New York: The Twentieth Century Fund.

Tripathi, S. and N. Leitão, 2013. India's trade and gravity model: A static and dynamic panel data. Germany: University Library of Munich.

UNCTAD, 2013. Economic development in Africa report 2013: Intra African trade, unlocking private sector dynamism.

Vicard, V., 2011. Determinants of successful regional trade agreements. Economics Letters, 111(3): 188-190. Available at: https://doi.org/10.1016/j.econlet.2011.02.010.

Wang, Z.K. and L.A. Winters, 1992. The trading potential of Eastern Europe. Journal of Economic Integration, 7(2): 113-136. Available at: https://doi.org/10.11130/jei.1992.7.2.113.

WB, 2014. World Development Indicators. Edn., 2014. IN International, E. (Ed.) University of Manchester.

World Bank, 2013. World development indicators. In: International, E. (Ed.). University of Manchester.

Zannou, A., 2010. Determinants of intra-ECOWAS trade flows. African Journal of Business Management, 4(5): 678-686. 